\title{
Palestinian Entrepreneurs in Honduras: A Case of Success and Triumph in the Diaspora
}

\author{
Husam Omar.,PhD \\ hkomar@hct.ac.ae \\ Faculty of Business, Higher College of Technology, United Arab Emirates \\ Monica Gallant.,PhD \\ Faculty of Business, Higher College of Technology, United Arab Emirates
}

\begin{abstract}
Through the years, Palestinians have immigrated to Central America where they have been able to assimilate into a diverse cultural environment while still maintaining a strong link to their cultural heritage. Additionally, certain individuals have been able to prosper financially through the development of increasingly significant business enterprises. Through an analysis of in-depth interviews with three successful Palestinian entrepreneurs now established in Honduras, it is evident that these immigrants used energy, wit, common sense, hard work, and financial resources not only to survive but also to flourish. Their stories highlight how their success developed from peddling, to business ownership, to stock market investing.

Keywords: Palestinian entrepreneurs, Honduras, abonos, peddling
\end{abstract}

\section{Introduction}

This paper aims to gain a deeper understanding of the journey that was taken by Palestinian sojourners in three main waves of immigration from the Holy Land (Palestine) to Central America and in particular, to the small country of Honduras. It will further explore their remarkable successes, assimilation, and involvement in every aspect of life in this small Central American country. The evidence of this phenomenon can be seen through observing that many students studying in an American University in Texas had Latin or Spanish first names and oddly enough had Palestinian last names. These individuals proudly identified themselves as Hondurans, but they were equally proud and spoke passionately about their heritage and national origins rooted in the politically tempestuous land of Palestine. This paper was constructed using interviews with Hondurans whose ancestors came from Palestine years ago and who still identify culturally as Palestinians.

\section{Historical Background}

Of the seven Central American countries: Guatemala, Nicaragua, El Salvador, Belize, Costa Rica, Panama, and Honduras, Honduras is the home of the largest Palestine community in Central America. El Salvador hosts the second largest community. Immigration to Central America began in the late $19^{\text {th }}$ century with the newly implemented economic liberal reforms of a number of Central American countries like Honduras, during the period from 18601915 (Boosahada, 2003)

Marco Soto of Honora, the reformist capitalist president of Honduras from 1876 to 1883 , considered immigration to be a formative factor in the economic development of his country and Central America as a whole. The immigrants who arrived during that time were mainly Christian Catholics from Bethlehem in Palestine. This was considered the first of three waves of Palestinian immigration to Central America. The second wave of immigration occurred from 1925 to 1965 during which time the devastating war of 1948 took place causing the displacement of a large number of

The current issue and full text archive of this journal is available at www.jraspublications.org/index.php/JRAS/issue/archive Journal of Research in Administrative Sciences (JRAS) V IX(II), 36-39, ISSN: 2664-2433
Palestinians who left their homeland to find refuge elsewhere. The third wave of immigration to Central America took place after the six-day war in 1967, a humiliating war that shattered the dreams of millions of Arabs. While millions of Palestinians sought refuge in Arab countries surrounding Palestine, a large number of them followed their families to Honduras in Central America (Guzman \& Zeraoui, 2003).

The large extent of immigration during this period is attributed mainly to the savagery of wars that produced poverty as well as the compulsory draft obligation that required males to join the Ottoman army to fight in remote, harsh places like Eastern Europe. In addition, heavy-handed government corruption, lack of educational opportunities, lack of employment, and poor economic outlook fueled the desire to seek a new home. These challenging conditions precipitated immigration mainly among young males who were willing to bear the hardship of the journey which would take up to 60 days at sea (Aswad, 1993).

According to Hourani and Shehadi (1992), the second wave of immigration witnessed an unlimited influx to North and South America, despite restrictions imposed by the Ottoman government who saw immigration as draining the pool of potential soldiers that could fight its war in Europe and the Middle East. According to some estimates, the number of immigrants from the late 1800 s to 1919 reached 250,000, most of which came from the Levant, which is the area east of the Mediterranean, or what used to be named Greater Syria.

The push conditions created by rising Turkish nationalism combined with the pull of economic prospects created "chain migration" with siblings, the extended family or the entire family leaving everything behind to join family members abroad. Across the US and Latin America, immigration officers did not distinguish between different nationalities at this time because the entire Middle East and the Levant were un der the control of the Ottoman empire; therefore, all 
Palestinian Entrepreneurs in Honduras: A Case of Success and Triumph in the Diaspora

Husam Omar., PhD, Monica Gallant., PhD

immigrants from the Levant region, whether they were Arabs, Armenians or Jews, were categorized as Turks, or Turcos. Palestinians immigrants made up a small portion of the total 1.2 million Ottoman citizens that comprised the great wave of immigrants who arrived in the New World between the years of 1860 and 1915 (Karam, 2007).

\section{Business Environment}

Under the liberal economic reforms of the Honduran president Marco Soto, who was intent on nation-building, immigration was considered to be an engine of economic growth and instrumental to the development and the ultimate success of capitalism in Central America as a whole. Palestinian immigrants to Honduras initially dedicated themselves to simple commercial activities which were well supported by the liberal capitalism of President Soto during this period. They learned the Spanish language that was necessary for their commercial and business enterprises, and in some cases, they also learned other local languages in order to do business with remote populations that retained their native language. Early Palestinian immigrants practiced ambulatory commerce trading in basic goods like shoes, fabric, mirrors, needles, combs and other household products (Kayyali, 2006). They traveled from house to house and from one town to the other in the remote underserved regions of the country. They established a loyalty and bond with their customers creating trust which then led to offering their customers terms of sale on credit. This innovative idea of selling to customers on a credit system gave poor families the chance to buy pricy items like good quality dresses by paying in installments called "abonos" (Alfaro-Velcamp, 2007).

Palestinian immigrants played an important role in itinerant commerce and soon their name "Turcos" would become synonymous for peddlers (Zeraoui, 2007). Peddling goods was a difficult job but lucrative and financially satisfying which eventually enabled those immigrants to develop from running itinerant commercial activities into a consolidation of their businesses in several cities, particularly in the city of San Pedro Sula. Over time, large stores were established expanding their businesses into textiles and manufactured products, leaving the practice of ambulatory business to newly-arrived immigrants. As noted, the introduction of the Middle Eastern system of allowing poor customers to pay in installment "abonos" gave this newly rising community a competitive advantage over other local merchants thus helping them to expand their business network and increase their profits. Very soon those Palestinian immigrants accumulated enough capital between peddling and their retail stores to eventually become industrialists. Family-based connections and ties were instrumental in strengthening the network. Lesser (1999) noted that "Using ethnicity to construct strong business relations provides new economies of scale."

The strong economic, ethnic, and family links created a network of entrepreneurs, called impresarios, although this network was informal and based on oral commitment, it offered many of the new immigrants the chance to participate in the Honduran economy by providing startup capital. As some of these entrepreneurs began to improve their economic positions, a different kind of ambition arose; an ambition that would lead them to higher social standing, in which they ostentatiously emphasized their foreign roots to explain and justify their successes.

According to Manzar (2011), the economic contribution of the Palestinian immigrant in Honduras is evident, they excelled and dominated in key industrial sectors such as energy, banking, and media, helping employ a large number of people and stimulating the economy. The Arab immigrants worked hard to successfully integrate into their new community and achieve prominence in society. They formed a new oligarchy controlling the resources and having a major impact on the political structure in the country. The political coup of 2009 , for example, was seen as being instigated by the business sector, prompting a negative back clash against the Palestinian community in subsequent years, which some have described as a xenophobic campaign against the Turacos. As Knowlton (1955) stated, Arabs, in general, were familiar with peddling having had experience in their home country before embarking on their sojourns to the Americas. Peddling provided a lucrative cash flow that enabled them to save enough money to start their own businesses at a later date. They sold on credit at low prices, accepted local commodities as payment, and used their close community and family network to build their businesses (Kayyali, 2006).

\section{Interview Data}

Mr. Jorge Cronfel (2019), a third generation Palestinian born in Honduras, is a successful businessman in textile manufacturing and very active in local politics as well. In response to a question about the kind of businesses his family engaged in, he said, "My grandparents, when they arrived, did not speak any Spanish at all, so they went into peddling consumer good in remote villages outside the urban centers because these areas were underserved. Little by little they improved their economic lot and opened their own wholesale business selling to newly arrived immigrants from the Holy Land and who would become, at a later stage, peddlers". He went to relate that Palestinians are now major participants in every industry and every sector, owning energy businesses, banks, soft drink companies and so on (Cronfel, 2019).

Mr. Cronfel's response was indicative of the economic and social status that Palestinians have achieved in Honduras. Cronfel also discussed the most influential Palestinians in Honduras including the richest Palestinian in Honduras, Mr. Miguel Facussa, Other wealthy and influential families include the Canavati, Handal, and Kattan families (Cronfel, 2019).

Cronfel further indicated in his interview that Palestinian immigrants, who considered themselves as outsiders at the outset were not constrained by any cultural norms of their host societies, hence, they were at ease in choosing business as their profession. Most of the new Palestinian immigrants intended to go back or return to Palestine at some point in the near future, so it was commerce that mainly attracted them. In fact, most of them turned down land grants offered to them by the government to promote agricultural development. Many of them also moved to the Northern coastal zone and San Pedro Sula, the country's second largest city, where the growth of Banana plantations was at its peak. According to Cronfel, in the absence of an experienced Honduran merchant class, Palestinian immigrants essentially took over the commercial network in the Northern part of the country. An estimated $50 \%$ of the sales taxes that were remitted to the government in 1925 were paid by Arab owned businesses. At one point in time, Arab shop owners, $95 \%$ of whom were Palestinians, controlled most major businesses, especially large businesses. Palestinian investment had expanded exponentially particularly in the industrial sector where it grew quickly. By the 1960 s, it reached $75 \%$ of the import/export sector and close to $50 \%$ of the manufacturing sector, which gave the Palestinian community an edge in controlling manufacturing employment. By the 1980s, Palestinian entrepreneurs with names like Handal, Kafai, Kattan, and Hasbun were on the list of the most important groups that controlled businesses (Cronfel, 2019).

Carlos Kattan (2019) is another Spanish-speaking Honduran with Palestinian ancestry. Through email correspondence, he recalled his grandfather telling him as he was growing up, 'respect commercial activities; commercial activities and their purpose rests in the small profit on sales. They ought to deal directly with consumers and ought to furnish them with fine cheap articles giving payment options while keeping the highest decency and integrity'. Carlos' grandfather who lived to be 95 years old, immigrated to Honduras in the 1920s via New York and Mexico, developing innovative products and providing good services to his customers. Carlos followed his grandfather's advice and currently symbolizes the ideal Honduran citizen with a Palestinian background; he is wealthy, his kids are wealthy, he is proud of his "Palestinianess" and stays connected to his Palestinian community and ancestry. He built a large and prosperous business empire that includes manufacturing, import/export, tourism, and other ventures. The story of Carlos Kattan represents the story of many in the 
Palestinian Entrepreneurs in Honduras: A Case of Success and Triumph in the Diaspora

Husam Omar., PhD, Monica Gallant., PhD

Palestinian community in Honduras and how they constructed their identity (Kattan, 2019).

Carlos spoke of his grandfather's hardships and difficulties in dealing with Honduran people in rural areas when he first arrived. Very few researchers focus on what compelled locals to deal with these foreigners coming from a far-away land; and how these foreigners with their growing knowledge of Spanish and local customs and norms attracted locals to trade and do business with them (Reynolds, 2002). According to Carlos Kattan, the Honduran people, particularly those who lived in the rural areas (campesinos), needed the Palestinian merchant's goods, consequently, they looked past the entrepreneurs 'foreignness' and viewed them simply as essential suppliers in a developing market economy. Palestinians also had to cut across ethnic boundaries and this ability afforded them a unique opportunity to establish themselves as decent, hardworking merchants who were willing to work and sell merchandise to the poor and middle classes. The Palestinians' system of allowing customers to pay in installments (abonos) gave this group of foreign entrepreneurs a competitive advantage over other merchants. This innovative system of doing business on credit served, albeit inadvertently, as a way to make foreign entrepreneurs acceptable in this community. This credit alternative to formal banking institutions was used by the Kattan family's successful enterprises which lead to the family's fortune by the late 1940s (Kattan, 2019)

The Palestinians' considerable entrepreneurial acumen enables them to achieve greater visibility in Honduras than in other neighboring countries where Palestinians have also immigrated, albeit in lesser numbers, like El Salvador and Nicaragua. According to Sayegh (1972), Middle Easterners never lacked entrepreneurial spirit. Throughout their history, they made their living by buying and selling, exporting and trading, serving as brokers or middlemen they are pioneers not afraid of taking risk. The prosperity gained by this distinguished group of immigrants to Honduras is partially explained by the notion that Middle Eastern immigrant culture is unique in its enterprising talent to make profits and their business acumen which is embedded in their cultural ability to prosper and succeed. This is in line with Benedict Anderson's (2006) concept of an imagined community. According to Anderson, a nation is a socially constructed community, imagined by the people who perceive themselves as part of that group, thus the Palestinian immigrants have drawn on their own cultural construction to find their niche in this new foreign land, which they now call home.

Salem Handal (2019) a third generation Honduran from Palestinian ancestry, is very aware of his origins and showed pride in his ethnicity that was apparent in his conversation. The Handal name became a household name in El Salvador in the 1980s because one of the Handals led a leftist guerilla group that fought a civil war against the corrupt right-wing government of Jose Napoleon Duarte until he signed a peace agreement under the auspices of US President, Ronald Reagan (Boosahada, 2003). Salem Handal talked about his grandfather's early days in Honduras when he arrived following the 1948 war which witnessed a large influx of Palestinian immigration to many countries in the Middle East and beyond. Handal (2019) talked about his grandfather saying,

"My grandfather was a peddler, most of his siblings were peddlers, all of his friends were peddlers. They did not learn the language and it was not easy for them to learn Spanish. They had a hard life. In those days the roads were not paved the way they are today so they had to use horses to move about between small remote communities in harsh weather sometimes away from their homes. At times they would knock on a door and the people would let them sleep in their homes because they felt sorry for them." In her description of peddlers and peddler's life, Louise Seymore Houghton, author of "The Syrian in the United States" (1911), wrote about Arab Immigrant Peddlers in the Americas:

"A peddler is a free man, a free woman, why should they give up the open air, the broad sky, the song of the bird, and the smile of the flowers and the right to work at will, free from work roles and free from taking orders from others."
Handal (2019) spoke very fondly of this grandfather and narrated what his grandfather told him about early Palestinian immigrants and their introduction to merchandising upon their initial arrival in Honduras,

"We started peddling at an early age and we received no training of any sort, language or anything else and we were just knocking on doors selling dry goods door to door, because the country and the language was so new, and by the time someone opened the door and by the time I thought of something to say in Spanish the door would be closed in my face. After this, I would go home and my family would ask me, how did it go today? And I would simply empty out my pocket and put the change indicating that I had a very tough day."

Women were instrumental in providing an anchor for the family. Whether they were wives or mothers, they usually stayed home and were responsible for budgeting the family finances. Women generally were of strong character and were in control of their lives and all of the family affairs. Frequently the husband gave his wife his earnings and she would give him, in turn, a certain amount of spending money. While attending schools, children helped their parents in successful enterprises, rent-producing stores, houses, and commercial establishments. Children worked on the property, worked in family stores or even worked outside the family business to bring in additional income. Multifarious and resourceful, Palestinian entrepreneurs used energy, wit, common sense and financial resources not only to survive but also to flourish. Their success developed from peddling, to business ownership, to stock market investing. They relied on gut feelings, common sense and strong family connections and family values. Their advancement in society resulted from hard work, commitment, discipline and the support of family and the community (Handal, 2019).

\section{Conclusion}

Presently, the Palestinians in Latin American and especially in Honduras are highly active and visible community members, both economically and politically. Most of them proudly have historical connections although, for some, it is considered a lost one. Now they are fourth and fifth generation Palestinians totally assimilated in their respective societies. The connection to Palestine shows up in a surname, family memory with some anecdotes, or culinary practices.

This research helps to identify the attributes of the Palestinian community that led to its success in Honduras. Exploring the Palestinian community in a country like Honduras is not an easy task because this community who managed to a certain degree to keep its distinct identity is also to a large degree assimilated. Palestinians in Honduras and other South American countries like Chile have fully integrated into the host country's social fabric "while preserving cultural identity" (El-Hattar 2011, 203). Today Palestinians in Honduras consider themselves citizens of this Central American country, their adopted country. Handal said, "I am proud to be Honduran, but I am also proud to be Palestinian" (2019).

Future research in this area could explore many aspects and factors of ethnic immigrant entrepreneurs in Honduras and other surrounding countries like Belize and El Salvador. Access to information might prove to be challenging, but that can be overcome through meticulous planning and rich networking.

\section{References}

i. Alfaro-Velcamp, T. (2007). So Far from Allah, so close to Mexico: Middle Eastern immigrants in modern Mexico. Austin, Texas: University of Texas Press.

ii. Anderson, B. (2006). Imagined Communities: Reflections on the origin and spread of Nationalism. London: Verso.

iii. Aswad, B. (1993). Arab Americans: Those who followed Columbus. Mesa Bulletin. Retrieved from http://fp.arizona.edu/mesa

iv. Boosahada, E. (2003). Arab-American faces and voices: The origins of an immigrant community. Austin, Texas: University of Texas Press. 
v. Cronfel, J. (March 08, 2019). Businessman. (H. Omar, Interviewer)

vi. El-Hattar, H. (2011). Palestinian and the Jewish communal press in Chile: The case of Al-Damir and La Palabra Israelita. Latin America and Caribbean Ethnic Studies, V. 6, n 2, p 189206.

vii. Guzman, R. M., \& Zeraoui, Z. (2003). Arab immigration in Mexico in the nineteenth and twentieth century. Austin, Texas: Morgan Printing.

viii. Handal, S. (March $11^{\text {th }}$ ，2019). Businessman. (H. Omar, Interviewer)

ix. Houghton, L. S. (1911). Syrian in the United States. The Survey: A Journal of Construction Philanthropy, 26-27.

x. Hourani, A., \& Shehadi, N. (1992). The Lebanese in the World: A Century of Emigration. Oxford: The Centre for Lebanese Studies in association with I.B. Tauris \& Co. Ltd, London.

xi. Karam, J. T. (2007). Another Arabesque, Syrian-Lebanese ethnicity in neoliberal Brazil. Philadelphia: Temple University Press.

xii. Kattan, C. (February 22 $\left.2^{\text {nd }}, 2019\right)$. Businessman. (H. Omar, Interviewer)

xiii. Kayyali, R. A. (2006). The Arab Americans. Westport: Greenwood Press.

xiv. Knowlton, C. S. (1955). The social and spacial mobility of the Syrians and Lebanese in the city of Sao Paulo, Brazil, Ph.D. Thesis. Nashville: Vanderbilt University.

xv. Lesser, J. (1999). Negotiating National Identity: Immigrants, minorities, and the Struggle for Ethnicity in Brazil. Kansas City: The Ewing Marion Kauffman Foundation.

xvi. Manzar, F. (2011). Palestinians in Central America: From Temporary Emigrants to a Permanent Diaspora. Journal of Palestinian Studies, V. 40, N 3:6:11.

xvii. Reynolds, P. D. (2002). The entrepreneur next door: Characteristics of individual starting companies in America. Kansas City: The Ewing Marion Kauffman Foundation.

xviii. Sayegh, Y. A. (1972). Entrepreneurship of Lebanon: The role of the business leader in a developing economy. Cambridge: Harvard Business Press.

xix. Zeraoui, Z. (2007). Arab immigration in South America in the early twentieth century. Austin: Morgan printing. 